\title{
The Triggering Factors of Preferred Customer's Loyalty in Sharia Banking
}

\author{
Audia JUNITA ${ }^{1 *}$, Tengku Lyza TAHURA², Muhammad REZA ${ }^{3}$ \\ 1,2,3 Faculty of Economics and Business, Harapan University of Medan, Indonesia \\ Email: audia.junita@yahoo.com¹, tengkulyza@gmail.com², mhdrezaa12@gmail.com³ \\ * Corresponding Author
}

$\begin{array}{llll}\text { Received: 17.11.2021 } & \text { Accepted: 06.12.2021 } & \text { Published: 02.02.2022 } & \text { DOI: 10.47750/QAS/23.186.21 }\end{array}$

\begin{abstract}
This study aims to determine the effect of service quality on customer loyalty with satisfaction and trust as moderating variables at PT. Bank Sumut Sharia. The research design is an explanatory type. The research population is all preferred customers at Bank Sumut Sharia with a total of 113 customers determined by nonprobability sampling. The analysis technique uses moderated regression analysis with residual method. The results of the study prove that the service quality variable has a significant effect on preferred customer loyalty. The variables of satisfaction and trust did not significantly moderate the influence of service quality variables on preferred customer loyalty. The indicator of satisfaction variable that contributes to low preferred customer's loyalty is performance. An indicator of trust that contributes to low preferred customer's loyalty is the benevolence dimension.
\end{abstract}

Keywords: Service Quality, Satisfaction, Trust, Loyality, Preferred Customer

\section{Introduction}

Banking practices have become commonplace in almost all parts of the world to make it easier for people to save money, transact and carry out financial activities, as well as in Indonesia. Bank according to Undang-Undang No. 10 / 1998 is a business entity that collects funds from the public in the form of savings and distributes them to the public in the form of credit/or other forms in order to improve the standard of living of the people. According to Abdurrachman (2014) the notion of a bank is a financial institution that carries out various kinds of services, such as providing loans, circulating currency, supervising currency, storing a valuable objects, business financing, and others.

In the banking industry, there are categories for regular and preffered customers. Preferred customers are customers who have a special classification of savings balances that have been determined by the bank and will be customers who are treated specifically to get certain benefits. Being a priority customer makes the customer a member of the Very Important Person in the bank. Based on Nollet et al. (2012), preferred customer status is a customer who receives better treatment from other customers in terms of quality, product availability, support in the procurement process, delivery and price.

Various efforts have been made by Bank Sumut Sharia to maintain customer loyalty every year, including preffered customers. Bank Sumut Sharia has a strategy to improve service quality, satisfaction and trust that will shape customer loyalty. The customer is an important concern for the bank for the progress of the bank itself.

Customer loyalty is a customer's effort to keep saving and using bank services. Kotler \& Keller (2012), Griffin (2003),
Tjiptono (2012) define customer loyalty as a situation where customers consistently and continuously buy products or services from the same seller from a selected company, despite the influence of the situation and marketing efforts which potentially lead to customer switching. Foster and Cadogan (2000), suggested indicators of customer loyalty in 4 actions, namely:

a. Behavior of customers who provide recommendations and invite others to use the product.

b. Customers will use all forms of services offered by the bank.

c. Customers make the bank as the main choice in using financial services.

d. The customer's behavior who talk about positive things about the bank's products and services to other people.

Various factors can determine customer loyalty. Quality of service is one of them. According to Kotler and Keller (2006), service quality affects consumer satisfaction and will shape interest in buying or reusing products. Research proves that service quality contributes significantly to individual motivation to take actions that benefit the organization (Hsieh et al., 2018; Pahala et al., 2021). Consumer resources become an important asset to create value for the company. Service quality in the context of communication is one of the strategies to foster good relationships and customer loyalty in the long term (Purohit, 2015; Nanda et al., 2021).

This study focuses on analyzing the direct and indirect effects of service quality on customer loyalty with customer satisfaction and trust as moderating variables. Service is any action or activity that one party can provide to another that is intangible and results in ownership (Kotler \& Amstrong, 2008). According to Lewis (1993), Lupiyoadi, (2001), Kotler \& Keller (2012), service quality is a measure of how well the level of 
service provided is able to meet customer expectations. Service quality must start from customer needs and end at customer perception. Customer perception of the quality of service received is one of the determinants of marketing success, namely performance of business (Petr et al, 2021). Parasuraman et al. (1988) suggested 5 main indicators of service quality, namely:

a. Reliability is the company's ability to provide services in accordance with what has been promised at the right time.

b. Responsiveness is the company's capacity to provide services quickly and responsively through the efforts of staff.

c. Assurance is behavior and knowledge of staff to foster a positive impression of consumers towards the company in the form of trust and confidence in the services received.

d. Empathy is the company's capacity to provide access in the form of ease of using the company's services.

e. Tangibles are tangible evidence of the care and attention that service providers give to consumers.

Service quality is a factor that can foster customer satisfaction and trust. Quality is the main determinant of customer satisfaction (Anderson et al, 1994). Research results confirm this relationship in the banking sector (Zavareh, 2012) even specifically in groups such as students (Yilmaz et al., 2018). Research results prove that in addition to customer satisfaction, service quality is a factor driving customer loyalty (Osman et al., 2015; Morreira \& Silva, 2015; Ayah, 2017; Haryeni et al., 2017; Alnaser et al., 2017; Suseno \& Suddin , 2017; Keshavarz \& Jamshidi, 2018; Boonlertvanich, 2018; Batin, 2019; Asiati et al., 2019; Mahfuz et al., 2020; Riyadi, 2020). Therefore, researchers suspect that service quality variables affect the emergence of customer satisfaction, trust and customer loyalty. Based on the various research findings, the statement of hypothesis 1 of this study is that service quality has a significant effect on preferred customer loyalty at Bank Sumut Sharia Medan.

Customer satisfaction reflects the level of success of the producer or service provider. According to Tjiptono (2012) customer satisfaction is the result of customer evaluation of the difference between initial expectations before purchase and actual product performance after consuming the product/service. According to Tjiptono (2008), evaluation of certain companies, products and services refers to various factors, namely:

a. Performance of a purchased core product.

b. Additional features.

c. Reliability is the probability of damage or failure of the product.

d. Conformance to specifications is a design and operating characteristic that meets specified standards.

e. Durability relates to the economic duration of product use.

f. Service ability, including speed, competence, comfort, ease of repair and after-sales service.

g. Aesthetics, namely the attractiveness of the product in terms of physical form, model/design, color, and so on.

h. Perceived quality, namely the image and reputation of the product.

According to Ehigie (2006), customer satisfaction has a direct effect on customer loyalty in Nigerian banking. Satisfaction is a derivative of perceived quality and an appropriate predictor of customer loyalty (Bitner and Hubbert, 1994). Oliver (1999) says that customer satisfaction is the main cause of brand loyalty. Various research results also prove the same thing that customer satisfaction has a significant effect on the emergence of loyalty (Hill et al., 2007; Shahrokh et al., 2013; Morreira \& Silva, 2015; Kumalaningrum et al., 2016; Ngo \& Nguyen, 2016; Rofiah \& Wahyuni, 2016; Setiawan, 2016; Haryeni, et al., 2017; Alnaser et al., 2017; Kasiri et al., 2017; Keshavarz \& Jamshidi, 2018; Asiati et al., 2019; Batin, 2019; Özkan, 2020; Mahfuz et al., 2020). However, the results of these studies are different from those of Bernarto et al. (2019) and Saleem et al. (2017) which states that satisfaction does not have an impact on increasing loyalty. This result is different from the results of other studies which state that customers who are satisfied with the product or service obtained will have a high tendency to continue their relationship with the company. Based on the differences from the results of the previous studies, the satisfaction variable was placed as the moderating variable in this study. Hypothesis 2 research is service quality has a significant effect on preferred customer loyalty moderated by customer satisfaction.

Trust is a strong foundation for a business to grow. Building customer trust is an important strategy for companies to build long-term relationships and customer loyalty (Morgan \& Hunt, 1994). According to Flavian \& Giunaliu (2007), trust is the confidence level of a certain party towards another party during a transaction relationship based on a deep belief that the other party he trusts can carry out all his obligations as expected. Trust is generated when customers observe employee knowledge and responsiveness (Parasuraman et al., 1988). The indicators of trust according to Flavian and Giunaliu (2007) are:

a. Honesty (honesty), is an attitude of honesty and the absence of lies and deceit.

b. Virtue (benevolence), is an action that puts the public interest above personal interests.

c. Competence is the perception of knowledge, the ability to solve problems and meet the needs of others.

Previous empirical and theoretical studies have proven that trust has a positive and significant effect on customer loyalty (Nayebzadeh, et al., 2013; Saeed, et al., 2014; Morreira \& Silva, 2015; Haryeni et al., 2017; Suseno \& Suddin, 2017 ; Saleem et al., 2017; Boonlertvanich (2018), Bernarto et al. 2019; Batin, 2019). Based on Swan and Nolan (1985), longterm customer loyalty will be realized if the customer has a high level trust in the product or company. However, the results of this study are different from the research conducted by Asiati et al. (2019) which states that trust has no significant effect on loyalty. Islamic bank customers do not fully trust Islamic banks. Based on these contradictory findings, the statement of the research hypothesis is that service quality has a significant effect on preferred customer loyalty which is moderated by satisfaction.

Based on a review of various relevant previous studies related to the factors forming customer loyalty, it was identified that there were inconsistencies in research findings related to the influence of satisfaction and trust variables on customer loyalty. For example, based on Seiler et al. (2013) and Ozkan (2020) it is proven that satisfaction has a positive and significant effect on customer loyalty, while the research of Bernarto et al. (2019) proves something different that satisfaction does not have a significant impact on increasing loyalty. Likewise for the influence of the trust variable on loyalty, based on research by Haryeni et al. (2017) it is proven that trust has a positive and significant effect on customer loyalty, while the research of Asiati et al. (2019) proves that trust has no significant effect on customer loyalty. Based on these research findings, researchers are interested in placing and analyzing the variables of satisfaction and trust as 


\section{GENERAL MANAGEMENT}

moderating variables in the influence of service quality on preferred customer loyalty of PT Bank Sumut Sharia. This is become the significance of the study that distinguishes it from previous studies. Based on this background, the researcher is interested in conducting research that focuses on "The Trigerring Factors of Preferred Customer's Loyalty PT. Bank Sumut Sharia".

\section{Research Model}

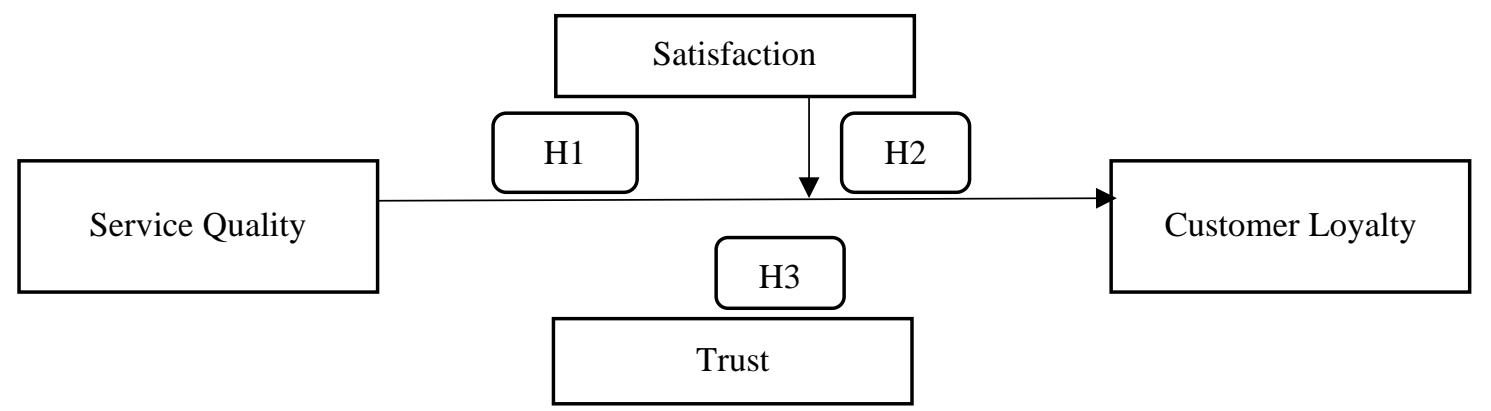

Figure 1: Research Model

\section{Method}

This type of research is explanatory research that aims to analyze the effect of two or more variables (Sugiyono, 2016). The research population is the preferred customers of Bank Sumut Sharia with a total of 145 people. The entire population became the research sample so that the determination of the sample was based on a non-probability sampling technique, namely saturation sampling. Research variables include several variables The independent variable is the quality of service as measured by 5 indicators Parasaruman et al. (1988) namely: reliability, responsiveness, assurance, empathy, and tangibles. Moderating variables include satisfaction and trust. The satisfaction variable is measured by 4 indicators proposed by Tjiptono (2008), namely performance, features, service ability, and perceived quality. The trust variable is measured by 3 indicators of Flavian and Giunaliu (2010), namely honesty, benevolence, and competence. The dependent variable is customer loyalty as measured by 4 indicators Foster and Cadogan (2000), namely the behavior of recommending other parties to make purchases, using everything offered by the bank, making banking the first choice in using financial services, and marketing products with the word of mouth technique. mouth. Primary research data were collected by distributing questionnaires. The data analysis technique used inferential and descriptive statistics. Moderation regression analysis using the residual tmethod (Ghozali, 2016). Cross tabulation was used to justify the findings of the test results with ineferential statistics.

\section{Results}

Respondents in this study are preferred customers at PT. Bank Sumut Sharia, namely customers who have been registered and have a minimum balance of Rp. 250,000,000 with an initial population of 145 preffered customers. Researchers distributed questionnaires using google forms and distributed them to the entire population. From the 145 questionnaires distributed, only 113 respondents were willing to return the questionnaires, and as many as 32 preffered customers did not provide answers. Thus the researchers made the 113 data as samples used in data processing. The following is a demographic profile of research respondents.

\begin{tabular}{|c|c|c|}
\hline Characteristics & Categories & Total (\%) \\
\hline Gender & $\begin{array}{l}\text { a. Male } \\
\text { b. Female }\end{array}$ & $\begin{array}{l}53 \text { people }(47 \%) \\
60 \text { people }(53 \%)\end{array}$ \\
\hline Age & $\begin{array}{l}\text { a. }<30 \text { years old } \\
\text { b. } 30-40 \text { years old } \\
\text { c. }>40 \text { years old }\end{array}$ & $\begin{array}{l}16 \text { orang }(14 \%) \\
35 \text { orang }(31 \%) \\
62 \text { orang }(55 \%)\end{array}$ \\
\hline Occupation & $\begin{array}{l}\text { a. Businessmen } \\
\text { b. Entrepreneur } \\
\text { c. Private employees } \\
\text { d. Government employees } \\
\text { e. Military/Police }\end{array}$ & $\begin{array}{l}31 \text { orang }(27 \%) \\
20 \text { orang }(18 \%) \\
19 \text { orang }(17 \%) \\
12 \text { orang }(11 \%) \\
1 \text { orang }(1 \%)\end{array}$ \\
\hline Education Level & $\begin{array}{l}\text { a. Diploma/S1/S2/S3 } \\
\text { b. SMA }\end{array}$ & $\begin{array}{l}93 \text { orang }(82 \%) \\
20 \text { orang }(18 \%) \\
\end{array}$ \\
\hline $\begin{array}{l}\text { Length of time to be a } \\
\text { Priority Customer }\end{array}$ & $\begin{array}{l}\text { a. }>4 \text { years old } \\
\text { b. } 2-4 \text { years old } \\
\text { c. } 1-2 \text { years old } \\
\text { d. }<1 \text { years old }\end{array}$ & $\begin{array}{l}55 \text { orang }(50 \%) \\
34 \text { orang }(31 \%) \\
20 \text { orang }(18 \%) \\
4 \text { orang }(1 \%)\end{array}$ \\
\hline
\end{tabular}

Table 1: Respondents Profile

Source: processed data, 2021 


\section{GENERAL MANAGEMENT}

\section{Instrument Validity and Reliability Test}

Before testing the research hypothesis, the items on the questionnaire need to be tested for the validity and reliability of the instrument. The results of the validity test of all items on the variables of Service Quality (X), Satisfaction (Z1), Trust (Z2) and Customer Loyalty $(Y)$ have a value of $r$ arithmetic $>r$ table (0.184) so it is stated that all questionnaire items are valid. Based on the results of the variable reliability test, it was found that the value of Cronbach's Alpha variable Service Quality (X) was 0.951 , Satisfaction (Z1) was 0.940 , Trust (Z2) was 0.916 and Customer Loyalty $(Y)$ was 0.927 . These variables have Cronbach's Alpha values $>0.60$ so they are declared reliable.

\section{Classical Regression Assumption Test}

The classical assumption test of the regression research model includes normality and heteroscedasticity tests. The results of the normality test for the distribution of research data using the the Monte Carlo value of Kolmogrov-Smirnov Test (KS-Test). Sig KS-Test is 0.109 for the hypothesis model 1, 0.499 for the hypothesis model 2 , and 0.825 for the hypothesis model 3. All of the hree research models are greater than the significance level (a) of 0.05 , so it is concluded that the research model meets the assumption of normality. Then, it is feasible to test the hypothesis (Ghozali, 2016).

Heteroscedasticity test aims to test the variance inequality of another observation in the regression model. Heteroscedasticity test in this study was carried out by the Glejser method. Based on the results of the heteroscedasticity test, it was found that the significance value for the hypothesis model 1 was 0.907 , the hypothesis model 2 was 0.294 , and the hypothesis model 3 was 0.479 . The entire research model has a significance value of the Glejser test $>$ a significance level (a) of 0.05 so that the research model is declared free from heteroscedasticity symptoms (Ghozali, 2016).

\section{Hypothesis Testing}

Hypothesis 1 wants to prove the effect of service quality has a significant effect on customer loyalty. The results of hypothesis testing 1 in Table 1 show that the significance value $(p=0.000)$ is smaller than the research significance level (a) of 0.05 and the standard beta coefficient of 0.929 so that it can be concluded that the service quality variable has a positive and significant effect on customer loyalty.

\begin{tabular}{|c|c|c|c|c|c|}
\hline \multirow[b]{2}{*}{ Model } & \multicolumn{2}{|c|}{$\begin{array}{l}\text { Unstandardized } \\
\text { Coefficients }\end{array}$} & \multirow{2}{*}{\begin{tabular}{|l|}
$\begin{array}{l}\text { Standardized } \\
\text { Coefficients }\end{array}$ \\
Beta \\
\end{tabular}} & \multirow[b]{2}{*}{$\mathrm{T}$} & \multirow[b]{2}{*}{ Sig. } \\
\hline & $B$ & Std. Error & & & \\
\hline \begin{tabular}{|l|l}
1 & (Constant) \\
\end{tabular} & .091 & .135 & & .675 & .501 \\
\hline Service Quality & .979 & .037 & .929 & 26.523 & .000 \\
\hline
\end{tabular}

Table 2: Hypothesis Testing 1 Results

Source: processed data, 2021

Test the hypothesis 2 research to prove whether the service quality variable has a significant effect on customer loyalty moderated by satisfaction. The results of hypothesis testing 2 found that the significance value $(p=0.294)$ was greater than the research significance level (a) of 0.05 and the standard coefficient of beta was 0.100 and was positive. The requirement for a variable to be a moderating variable is that the significance value is less than 0.05 and the standard beta coefficient value is negative (Ghozali, 2016). Thus, it is concluded that satisfaction does not moderate service quality to preferred customer loyalty.

\begin{tabular}{|c|c|c|c|c|c|c|}
\hline \multirow{2}{*}{\multicolumn{2}{|c|}{ Model }} & \multicolumn{2}{|c|}{ Unstandardized Coefficients } & \multirow{2}{*}{\begin{tabular}{|l|} 
Standardized Coefficients \\
Beta
\end{tabular}} & \multirow[b]{2}{*}{$\mathrm{t}$} & \multirow[b]{2}{*}{ Sig. } \\
\hline & & $B$ & Std. Error & & & \\
\hline \multirow[t]{2}{*}{1} & (Constant) & .114 & .070 & & 1.620 & .108 \\
\hline & Loyalty & .020 & .019 & .100 & 1.054 & .294 \\
\hline
\end{tabular}

Table 3: Hypothesis Testing 2 Results Source: processed data, 2021

Hypothesis testing 3 research wants to prove whether the service quality variable has a significant effect on preferred customer loyalty moderated by trust. The results of hypothesis testing 3 found a significance value greater than 0.05 ( $p=$
0.479) above the research significance level (a) of 0.05 and the standard beta coefficient value of -0.711 with a negative coefficient direction. Thus it is concluded that trust does not moderate service quality on customer loyalty. 


\section{GENERAL MANAGEMENT}

\begin{tabular}{|l|l|l|l|l|l|l|}
\hline \multicolumn{2}{|l|}{ Model } & \multicolumn{2}{l|}{ Unstandardized Coefficients } & $\begin{array}{l}\text { Standardized } \\
\text { Coefficients }\end{array}$ & \multirow{2}{*}{ Sig. } \\
\cline { 3 - 5 } \multicolumn{2}{|l|}{} & B & Std.Error & Beta & \\
\hline \multirow{2}{*}{1} & (Constant) & .114 & .094 & & 3.344 & .001 \\
\cline { 2 - 4 } & Loyalty & -.018 & .025 & -.067 & -.711 & .479 \\
\hline \multicolumn{2}{|l|}{ a. Dependent Variable: ABS_RES2 } & & & \\
\hline
\end{tabular}

Table 4 : Hypothesis Testing 3 Results Source: processed data, 2021

\section{Discussion}

\section{The Effect of Service Quality on Preferred Customer Loyalty}

The results of testing the first hypothesis prove that service quality has a significant effect on customer loyalty (Table 2). The results of the first hypothesis test are supported by crosstabulation description data between service quality and customer loyalty in Table 5.

Based on the results of the cross-tabulation description test in Table 5, it appears that preferred customers who have high satisfaction also have high loyalty (39,8\%), and conversely there are no preferred customers who have low satisfaction and low loyalty $(0 \%)$. With these descriptive data, it can be stated that the perceived service quality of the preferred customer is related to the level of loyalty to PT Bank Sumut Sharia. The results of this study are in accordance with previous studies (Osman et al., 2015; Morreira \& Silva, 2015; Ayah, 2017; Haryeni et al., 2017; Alnaser et al., 2017; Suseno \& Suddin, 2017; Keshavarz \& Jamshidi, 2018 ; Boonlertvanich, 2018; Batin, 2019; Asiati et al., 2019; Mahfuz et al., 2020; Riyadi, 2020) which proves that service quality has a significant effect on customer loyalty. Thus it is concluded that Hypothesis 1 is accepted.

\begin{tabular}{|l|l|l|l|l|}
\hline $\begin{array}{l}\text { Service Quality } \\
\text { Customer Loyalty }\end{array}$ & Low & Medium & High & Total \\
\hline Low & 0 & 5 & 0 & 5 \\
\hline Medium & 1 & $(4,4 \%)$ & & $(4,4 \%)$ \\
\hline High & $(0,9 \%)$ & 50 & 4 & 28 \\
& 0 & $(44,2 \%)$ & $(3,5 \%)$ & $(48,7 \%)$ \\
\hline Total & & $(7,1 \%)$ & 45 & 53 \\
& 1 & 63 & $(39,8 \%)$ & $(46,9 \%)$ \\
\hline
\end{tabular}

Table 5 : Cross Tabulation Service Quality and Customer Loyalty Source: processed data, 2021

\section{The Effect of Service Quality on Preferred Customer Loyalty Moderated By Satisfaction}

Based on the results of testing the second hypothesis, it is known that satisfaction does not significantly moderate the relationship between service quality and customer loyalty (Table 3). This statement is supported by cross-tabulation description data between indicators of customer satisfaction and loyalty in Table 6 . The results of this hypothesis are also supported by frequency distribution data based on indicators of satisfaction variables consisting of performance, features, service ability, aesthetics and perceived quality. The high level of preferred customer loyalty at Bank Sumut Sharia is closely related to performance $(59.3 \%)$, features $(51.3 \%)$, service ability $(46.9 \%)$, aesthetics $(45.1 \%)$ and perceived quality (46\%).

\begin{tabular}{|l|l|l|l|l|l|}
\hline \multirow{2}{*}{$\begin{array}{l}\text { Customer Loyaty } \\
\text { Level }\end{array}$} & Satisfaction Level & \multicolumn{5}{l|}{} \\
\cline { 2 - 6 } & Performance & Features & Service Ability & Estetika & Perceived Quality \\
\hline \multirow{2}{*}{ Low $(1-2,33)$} & 12 & 7 & 7 & 5 & 8 \\
& $(10,6 \%)$ & $(6,2 \%)$ & $(6,2 \%)$ & $(4,4 \%)$ & $(7,1 \%)$ \\
\hline \multirow{2}{*}{ Medium $(2,34-3,67)$} & 34 & 48 & 53 & 57 & 53 \\
& $(30,1 \%)$ & $(42,5 \%)$ & $(46,9 \%)$ & $(50,4 \%)$ & $(46,9 \%)$ \\
\hline \multirow{2}{*}{ High $(3,68-5)$} & 67 & 58 & 53 & 51 & 52 \\
& $(59,3 \%)$ & $(51,3 \%)$ & $(46,9 \%)$ & $(45,1 \%)$ & $(46 \%)$ \\
\hline Total & 113 & 113 & 113 & 113 & 113 \\
\hline
\end{tabular}

Table 6 : Cross Tabulation of Customer Satisfaction and Loyalty Indicators Source: processed data, 2021 
Based on the data in Table 6, descriptively, the satisfaction indicator that contributes to low customer loyalty is the aspect of performance (10.6\%). Trust is a strong foundation for a business to grow. Building customer trust is an important strategy for companies to build long-term relationships and customer loyalty (Morgan \& Hunt, 1994).

Performance according to Tjiptono (2012) is the operating characteristics purchased for example speed, ease and convenience in using the product. The lack of facilities and conveniences such as features that make it easier for preferred customers to conduct financial transactions without having to come to the Bank has a tendency to make the performance level of Bank Sumut Sharia less. Because of the condition, it is preferred that customers who have high activities come directly to the Bank. Thus, it can be concluded that the satisfaction variable does not moderate the service quality variable on loyalty customer. The results of this study support the research conducted by Bernardo et al. (2019) and Saleem et al. (2017) which states that satisfaction does not have an impact on increasing loyalty.

\begin{tabular}{|l|l|l|l|}
\hline \multirow{2}{*}{$\begin{array}{l}\text { Customer Loyalty } \\
\text { Level }\end{array}$} & Trust Level & \multicolumn{2}{|l|}{} \\
\cline { 2 - 4 } & Honesty & Benevolence & Competence \\
\hline \multirow{2}{*}{ Low $(1-2,33)$} & 3 & 15 & 9 \\
& $(2,7 \%)$ & $(13,3 \%)$ & $(8 \%)$ \\
\hline \multirow{2}{*}{ Medium $(2,34-3,67)$} & 61 & 36 & 53 \\
& $(54 \%)$ & $(31,9 \%)$ & $(46,9 \%)$ \\
\hline \multirow{2}{*}{ High $(3,68-5)$} & 49 & 62 & 51 \\
\hline Total & $(43,4 \%)$ & $(54,9 \%)$ & $(45,1 \%)$ \\
\hline
\end{tabular}

Table 7 : Cross Tabulation of Customer Trust and Satisfaction Indicators Source: processed data, 2021

\section{The Effect of Service Quality on Preferred Customer Loyalty Moderated By Trust}

Based on the results of testing the third hypothesis, it is known that trust does not significantly moderate the relationship between service quality and customer loyalty (Table 4). This statement is supported by descriptive data cross tabulation between indicators of trust and customer loyalty can be seen in Table 8 .

The variable of trust is measured by the indicators of honesty, benevolence, and competence. The high level of preferred customer loyalty at Bank Sumut Sharia is closely related to these indicators. Based on the descriptive data in Table 8, the satisfaction indicator that contributes to low customer loyalty is the benevolence aspect. Benevolence is an action that prioritizes the public interest over personal interests. The relatively low level of benevolence means that Bank Sumut Syariah Medan still does not prioritize the interests of the company over the interests of preferred customers, causing the level of trust of preferred customers to decrease.

Thus it can be concluded that the trust variable does not moderate the service quality variable on customer loyalty. These results support the research of Asiati et al. (2019) which states that trust has no significant effect on loyalty and turns out to be Sharia bank customers. PT Bank Sumut Sharia needs to make various efforts to show the company's benevolence through various partnership activities with the

\section{Reference}

[1] Abdurrachman, A. (2014). Ensiklopedia Ekonomi Keuangan Perbankan. Jakarta: PT. Pradya Paramitya.

[2] Abd Ghani, M., Rahi, S., Mansour, M., Abed, H., \& Alnaser, F. M. (2017). Determinants of Customer Loyalty: The Role of Service Quality, Customer Satisfaction and Bank Image of Islamic Banks in Palestine. International Journal of Economics \& Management Sciences, 06(05). doi:10.4172/2162-6359.1000461

[3] Anderson, E. W., Fornell, C., \& Lehmann, D. R. (1994). Customer Satisfaction, Market Share, and Profitability: Findings from Sweden. Journal of Marketing, 58(3), 53-66. community so that positive perceptions arise in customers.

\section{Conclusion}

The results of the study provide several conclusions, namely the quality of service has a positive and significant effect on the loyalty of preferred customers of PT. Bank Sumut Sharia. High service quality can form high loyalty from the preferred customers of PT. Bank Sumut Sharia. Service quality has no significant effect on loyalty moderated by satisfaction. Satisfaction is not a moderating variable in this study. Service quality has no significant effect on loyalty moderated by trust. Trust is not an appropriate moderating variable in this study.

Based on these findings, it is recommended for PT Bank Sumut Sharia to improve service quality, especially for priority customers by adopting the use of banking technology that provides easier services for customers to manage their finances without having to come to the office, especially in the current pandemic conditions. Improving aspects of performance and benevolence for the better for Bank Sumut Sharia to be able to increase the level of satisfaction and trust to a higher level. Further research to identify the factors that shape preferred customer loyalty needs to be done to get a comprehensive picture regarding preferred customer loyalty.

doi: $10.1177 / 002224299405800304$.

[4] Asiati, D. I., Wibowo, Umar, H., \& Sitinjak, T. (2019). The Effects of Service Quality, Image and Trust on Satisfaction and Its Impact on Syari'ah Bank Customer Loyalty in Palembang. Business and Economic Research, 9(1), 295. doi:10.5296/ber.v9i1.14205

[5] Bapat, D. (2017). Exploring the antecedents of loyalty in the context of multi-channel banking. International Journal of Bank Marketing, 35(2), 174-186. doi:10.1108/ijbm-10-20150155

[6] Batin, M. H. (2020). Pengaruh Citra Bank, Kualitas Pelayanan, Kepercayaan Nasabah, Penanganan Keluhan, Dan Kepuasan Terhadap Loyalitas Nasabah Pada Bank Sumsel Babel Kantor Capem Syariah UIN Raden Fatah Palembang. MALIA: Journal of Islamic Banking and Finance, 
3(1), 45. doi:10.21043/malia.v3i1.5600

[7] Bernarto, I., Wilson, N., \& Suryawan, I. N. (2019). Jurnal Manajemen Indonesia, $19(1), \quad 80$. doi:10.25124/jmi.v19i1.1987.

[8] Bitner, M. J., Hubbert, A. R. (1994). Encounter Satisfaction Versus Overall Satisfaction Versus Quality. In Service Quality: New Directions in Theory and Practice. Chapter 3. California: Sage Publishing.

Chapter DOI:http://dx.doi.org/10.4135/9781452229102.n3.

[9] Boonlertvanich, K. (2019). Service quality, satisfaction, trust, and loyalty: the moderating role of main-bank and wealth status. International Journal of Bank Marketing, 37(1), 278302. doi:10.1108/ijbm-02-2018-0021.

[10] Osayawe Ehigie, B. (2006). Correlates of customer loyalty to their bank: a case study in Nigeria. International Journal of Bank Marketing, 24(7), 494-508. doi:10.1108/02652320610712102

[11] Flavian \& Giunaliu (2007), Measure on Web Usability Website. Journal of Computer Information System, 48(1), 1723.

[12] Foster, B. D., \& Cadogan, J. W. (2000). Relationship selling and customer loyalty: an empirical investigation. Marketing Intelligence \& Planning, 18(4), 185-199. doi:10.1108/02634500010333316

[13] Ghozali, I. (2016). Aplikasi Analisis Multivariete Dengan Program IBM SPSS. Semarang: Badan Penerbit Universitas Diponegoro.

[14] Haryeni, Mulyati, Y., Laoli, E.F. (2017). Kualitas Pelayanan, Kepercayaan Dan Kepuasan Nasabah Dan Pengaruhnya Terhadap Loyalitas Nasabah Pada Tabungan Bank Rakyat Indonesia (Persero) TBK kantor Cabang Khatib Sulaiman. Jurnal Ekonomi \& Bisnis Dharma Andalas, 19(2), 189-201.

[15] Hill, N., Roche, G., Allen, R. (2007). Customer Satisfaction: The Customer Experience through The Customer's Eyes. United Kingdom: The Leadership Factor.

[16] Hsieh, C.-M., Chen, T.-P., Hsieh, C.-J., \& Tsai, B.-K. (2018). Moderating effect of membership status on the quality-valueloyalty chain at museums. Social Behavior and Personality: An International Journal, 46(1), 107-126. doi:10.2224/sbp.4073 .

[17] Kasiri, L. A., Guan Cheng, K. T., Sambasivan, M., \& Sidin, S. M. (2017). Integration of standardization and customization: Impact on service quality, customer satisfaction, and loyalty. Journal of Retailing and Consumer Services, 35, 91-97. doi:10.1016/j.jretconser.2016.11.007

[18] Keshavarz, Y., \& Jamshidi, D. (2018). Service quality evaluation and the mediating role of perceived value and customer satisfaction in customer loyalty. International Journal of Tourism Cities, 4(2), 220-244. doi:10.1108/ijtc-092017-0044

[19] Kotler, P. \& Keller, K.L. (2006). Marketing Management. 12th Edition. Upper Saddle River: Prentice Hall.

[20] Kotler, P. \& Amstrong, G. (2008). Principles of Marketing. New Jersey: Pearson/Prentice Hall.

[21] Kotler, P. \& Keller, K.L. (2012). Marketing Management. 14th Edition. New Jersey Prentice Hall.

[22] Kumalaningrum, F., Widajanti, E., Sutarno (2016). Analisis Pengaruh Kualitas Pelayanan Terhadap Loyalitas Konsumen Dengan Kepuasan Konsumen Sebagai Variabel Moderasi (Studi Pada Konsumen CS Kopi Tubruk Surakarta). Jurnal Ekonomi dan Kewirausahaan, 16(2), 226-233.

[23] Lewis, B. R. (1993). Service Quality: Recent Developments in Financial Services. International Journal of Bank Marketing, 11(6), 19-25. doi:10.1108/02652329310045729.

[24] Lupiyoadi, R. (2001). Manajemen Jasa, Teori dan Praktik Edisi Pertama. Penerbit Salemba Empat, Jakarta.

[25] Mahfuz, D.S., Lubis, P. H., Utami, S. (2020). The Effect of Religiosity and Service Quality on Customer Satisfaction and Its Impact on Priority Customer Loyalty of Sharia Mandiri
Bank Branch Banda Aceh. International Journal of Scientific and Management Research, 3(3), 48-54.

[26] Ngo, M. V., \& Nguyen, H. H. (2016). The Relationship between Service Quality, Customer Satisfaction and Customer Loyalty: An Investigation in Vietnamese Retail Banking Sector. Journal of Competitiveness, 8(2), 103-116. doi:10.7441/joc.2016.02.08

[27] Moreira, A. C., \& Silva, P. M. (2015). The trust-commitment challenge in service quality-loyalty relationships. International Journal of Health Care Quality Assurance, 28(3), 253-266. doi:10.1108/ijhcqa-02-2014-0017

[28] Morgan, R. M., \& Hunt, S. D. (1994). The Commitment-Trust Theory of Relationship Marketing. Journal of Marketing, 58(3), 20. doi:10.2307/1252308

[29] Nanda, A., Thayib, A., Wijayanti, R., Rofiaty. (2021). Customer Equity as Mediator of Customer Experience and Loyalty Relationship. Quality Access to Success, 22(185), 3137. DOI: https://doi.org/10.47750/QAS/22.185.05.

[30] Nayebzadeh, S., Arsalanizadeh, O., Sabrabadi, M.M. (2013). The Relationship Between Satisfaction, Trust, and Loyalty: Ebanking's

[31] Customers of an Iranian Bank (A Case Study: Melli Banks of Yazd Township). Journal of Basic and Applied Scientific Research, 3, 2090-4304.

[32] Oliver, R. L. (1999). Whence Consumer Loyalty? Journal of Marketing, 63, 33. doi:10.2307/1252099

[33] Osman, Z., Mohamad, L., Mohamad, R.K. (2015). An Empirical Study of Direct Relationship of Service Quality, Customer Satisfaction and Bank Image on Customer Loyalty in Malaysian Commercial Banking Industry. American Journal of Economics, 5(2), 168-176.

[34] Özkan, P., Süer, S., Keser, İ. K., \& Kocakoç, İ. D. (2019). The effect of service quality and customer satisfaction on customer loyalty. International Journal of Bank Marketing, 38(2), 384-405. doi:10.1108/ijbm-03-2019-0096

[35] Pahala, I., Hasanah, N., Khairani, R., Kiswanto, Suherman, Musyaffi, A. M. (2021). The Quality Effect of Service, Perception, Tax Payer Motivation of The Interest of Using Tax Consultant Services. Quality Access to Success, 22(185), 142-145. DOI: https://doi.org/10.47750/QAS/22.185.19.

[36] Parasuraman, V., Zeithamal, A., Berry, L.L. (1988). Servqual: A Multiple-Item Scale for Measuring Consumer Perceptions of Service Quality. Journal of Retailing, 16, 12-37.

[37] Purohit, H. . C. . (2015). Examining and Exploring the Relationships Between Customer Satisfaction and Customer Loyalty. Delhi Business Review, 16(2), 37-46. doi:10.51768/dbr.v16i2.162201517

[38] Petr, S., Simona, C., Hana, K., Stanislava, D. (2021). Business Financial Performance In The Context Of Customer Satisfaction Management, Quality Access to Success, 22(185), 124-135. DOI: https://doi.org/10.47750/QAS/22.185.17.

[39] Riyadi, S. (2020). Strategy Model For Improving Priority Customers Loyalty In Sharia Bank. Journal of Seybold Report, 15(9), 3853-3866.

[40] Dwi Wahyuni, C. R. (2017). Kualitas Pelayanan Dan Pengaruhnya Terhadap Loyalitas Pelanggan Yang Di Mediasi Oleh Kepuasan Di Bank Muamalat Jombang. Eksis: Jurna Riset Ekonomi Dan Bisnis, 12(1). doi:10.26533/eksis.v12i1.84

[41] Saeed, R., Iqbal, A., Lodhi, R.N., Sami, A., Riaz, A., Munir, M., Mizna (2014). Impact of Service Quality on Customer Loyalty in Islamic Banking Sector of Pakistan: A Mediating Role of Customer Satisfaction. Journal of Basic and Applied Scientific Research, 4(2), 135-143.

[42] Saleem, M. A., Zahra, S., \& Yaseen, A. (2017). Impact of service quality and trust on repurchase intentions - the case of Pakistan airline industry. Asia Pacific Journal of Marketing and Logistics, 29(5), 1136-1159. doi:10.1108/apjml-10-20160192 
[43] Seiler, V., Rudolf, M., \& Krume, T. (2013). The influence of socio-demographic variables on customer satisfaction and loyalty in the private banking industry. International Journal of Bank Marketing, 31(4), 235-258. doi:10.1108/ijbm-10-20120101

[44] Setiawan, H. (2016). PENGARUH KUALITAS LAYANAN, PERSEPSI NILAI DAN KEPERCAYAAN TERHADAP KEPUASAN DAN LOYALITAS PENGGUNA LAYANAN MOBILE BANKING. Jurnal Keuangan Dan Perbankan, 20(3). doi:10.26905/jkdp.v20i3.269

[45] Nollet, J., Rebolledo, C., \& Popel, V. (2012). Becoming a preferred customer one step at a time. Industrial Marketing Management, $\quad 41(8), \quad 1186-1193$. doi:10.1016/.j.indmarman.2012.10.003

[46] Sharokh, Z.D., Oveisi, N., Timasi, S.M (2013). The Effects of Customer Loyalty on Repurchase Intention in B2C ECommerce- A Customer Loyalty Perspective. Journal of Basic and Applied Scientific Research, 3, 634-644.

[47] Sugiyono (2016). Metode Penelitian Pendidikan, Cetakan Kelima Belas, Alfabeta, Bandung.

[48] Suseno, Y.D., Suddin, A. (2017). Analisis Pengaruh Kualitas Pelayanan, Kualitas Produk, Komtitmen Pelanggan Terhadap Loyalitas Pelanggan Dengan Kepercayaan Pelanggan Sebagai Variabel Moderasi (Survei Tentang UD Gas Elpiji Restuaji Surakarta). Eksplorasi, XXIX(2), 149-165.

[49] Swan, J.E. \& Nolan, J.J. (1985) Gaining Customer Trust: A Conseptual Guide For The Salesperson. Journal Personal Selling Sales Manager, 5(2), 39-48. DOI: https://www.tandfonline.com/doi/abs/10.1080/08853134.1985. 10754400.

[50] Tjiptono, F. (2008) Strategi Pemasaran Edisi Ketiga, Andi, Yogyakarta.

[51] Tjiptono, F. (2012). Strategi Pemasaran. Yogjakarta: Andi Offset.

[52] Undang-Undang Nomor 10 Tahun 1998 Tentang Perubahan Atas Undang-Undang Nomor 7 Tahun 1992 Tentang Perbankan.

[53] Zavareh, F. B., Ariff, M. S. Md., Jusoh, A., Zakuan, N., Bahari, A.Z., Ashourian, M. (2012). E-Service Quality Dimensions and Their Effects on E-Customer Satisfaction in Internet Banking Services. The 2012 International Conference on Asia Pacific Business Innovation and Technology Management, ProcediaSocial and Behavioral Sciences, 40, 441-445. https://cyberleninka.org/article/n/1103863.

[54] Yilmaz, V., Ari, E., Gurbuz, H. (2018). Investigating The Relationship between Service Quality Dimensions, Customer Satisfaction and Loyalty in The Turkish Banking Sector: An Application of The Structural Equation Model. International Journal of Bank Marketing, 36, 423-440. DOI: https://doi.org/10.1108/ijbm-02-2017-0037. 